
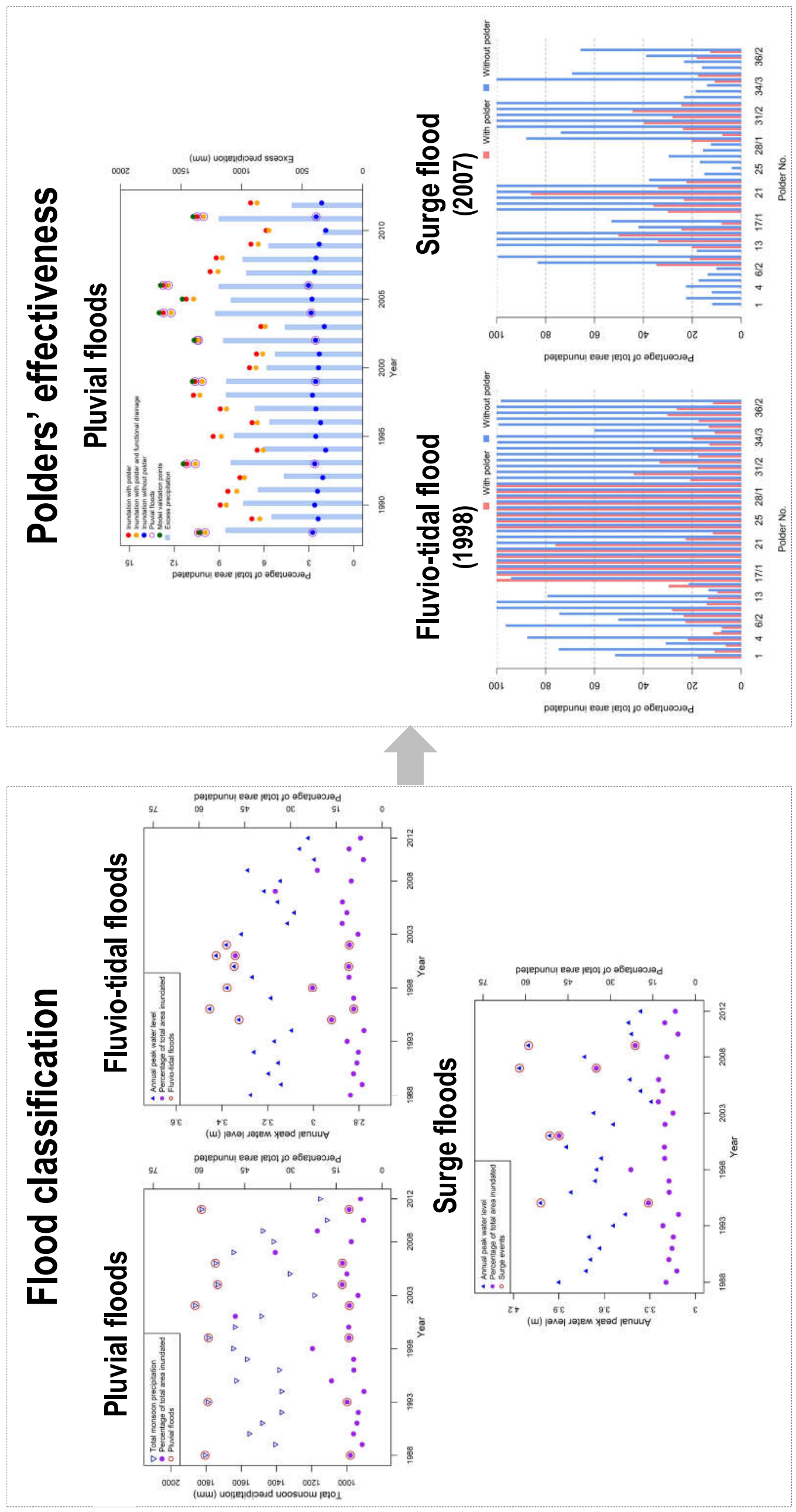
- We analysed floods in the coastal zone in Bangladesh in every year within 1988-2012

- Pluvial flooding resulted in $11.4 \%$ of the domain being flooded, on average

- Fluvio-tidal and surge floods were less frequent but caused more inundation

- Construction of the polders has increased the extent of pluvial flooded area

- Polders have provided some protection against storm surges and fluvio-tidal events 


\section{Have coastal embankments reduced flooding in Bangladesh?}

\section{Abstract}

3 From the 1960 s, embankments have been constructed in south western coastal region

4 of Bangladesh to provide protection against flooding, but the success of the polder

5 programme is disputed. We present analysis of floods during the years 1988-2012,

6 diagnosing whether the floods were attributable to monsoonal precipitation (pluvial

7 flooding), high upstream river discharge into the tidal delta (fluvio-tidal flooding), or

8 cyclone-induced storm surges. We find that pluvial flooding was the most frequent, but

9 typically resulted in less flooded area (11.44\% of the region on average) compared with the

10 other forms of flooding. The greatest area of inundation (48\% of total area) occurring in 2001

11 as a consequence of fluvio-tidal and surge flooding, whilst cyclone Sidr in 2007 flooded 35\%

12 of the area. We modelled these different forms of inundation to estimate what flooding might

13 have been had the polders not been constructed. For the 'no embankment' counter-factual

14 scenario, our model demonstrated that because of a combination of subsidence and

15 inadequate drainage, construction of the polders has increased the pluvial flooded area by

$166.5 \%$ on average $\left(334 \mathrm{~km}^{2}\right)$. However, during the 1998 fluvio-tidal flood, the embankments

17 protected an estimated $54 \%$ of the area from flooding. During the cyclone Sidr storm surge

18 event, embankment failure in several polders and pluvial inundation resulted in $35 \%$ area

19 inundation, otherwise, the total inundation would have been $18 \%$ area. We conclude that

20 whilst polders have provided protection against storm surges and fluvio-tidal events of

21 moderate severity, they have exacerbated more frequent pluvial flooding and promoted

22 potential flooding impacts during the most extreme storm surges.

23 Key words: Bangladesh coastal embankment; extreme events; flood classification; pluvial

24 flood; fluvio-tidal flood; storm surge flood 


\section{Introduction}

Structural flood defence systems are one response to flood hazards (Bamberg et al., 2017). While embankments, levees and dikes usually provide flood protection up to a given severity of flooding, these structures are costly and may exacerbate flooding under some circumstances, as well as potentially encouraging the build-up of exposed people and assets

30 (Hui et al., 2016).

Due to the deltaic geographical setting and high population density, Bangladesh is well-known as being vulnerable to flooding (Islam et al., 2016b; Moniruzzaman, 2012). The coastal region is subject to multiple flood hazards, including pluvial floods, which are inundations induced by monsoon precipitation, fluvio-tidal floods and storm surge-induced

35 floods (Abedin and Shaw, 2015; Alam et al., 2017; Brouwer et al., 2007; Haque et al., 2018;

36 Islam et al., 2016a). The impact of several catastrophic floods impelled the Bangladesh 37 government to construct coastal embankments in the 1960 s to protect agricultural land and 38 communities (Nishat et al., 2010; Paul and Rashid, 2017; Rahman and Salehin, 2013).

39 Coastal embankments have compartmentalized a portion of coastal region into polders. Their

40 construction was accompanied by the excavation of drainage channels and sluice gates to 41 impede salt water intrusion in the dry season, drain excessive rain water, and allow fresh river 42 water flow to polders in the wet season for irrigation purposes (Masud et al., 2018).

43 The coastal embankment programme had a profound influence on the geomorphology 44 of the coastal zone, as well as contributing to a transformation in human settlement patterns. 45 The embanked region experienced rapid land use change (Abdullah et al., 2019; Akber et al., 46 2018). In the last couple of decades, a substantial growth in shrimp farming, replacing 47 agricultural lands, is reportedly associated with soil salinity promoted by the intrusion of 48 saline water in polders (Mukhopadhyay et al., 2018). Moreover, storm surges and pluvial 49 flooding inundated agricultural lands, which has been reflected in a net reduction in land use 
50 for agriculture (Khan et al., 2015). In this naturally dynamic sediment system, reducing flow

51 in the channels of the delta, due to the separation of upstream river 'Mathabhanga' from the

52 river Ganges, caused siltation in the riverbed (Alam et al., 2017). Polders simultaneously also

53 impeded sedimentation within embanked region and resulted in land subsidence inside the

54 polders (Auerbach et al., 2015). As a result of reduced sediment supply or irregular

55 sedimentation, compaction of sediment, and anthropogenic activities (e.g. shrimp farming)

56 (Brammer, 2014; Brown and Nicholls, 2015), the coastal region on average experienced

57 about 2-3 mm/year of land subsidence (Brown and Nicholls, 2015). In addition, physical

58 deterioration and unreliable operation of the sluice gates caused prolonged inundation during

59 the monsoon period (Auerbach et al., 2015; Choudhury et al., 2004; Van Staveren et al.,

60 2017). The earthen embankments are subject to riverbank erosion which can breach the

61 polders, a process that can be exacerbated by tropical cyclones and lead to extensive flood

62 damage (Bhuiyan and Dutta, 2012; Haque and Nicholls, 2018). The polders have also been

63 criticized for their impact on coastal habitats and ecology (Roy et al., 2017).

64 Though these criticisms of polderization are widely reported (Alam et al., 2017;

65 Auerbach et al., 2015; Tareq et al., 2018), it has proved difficult to provide quantified

66 evidence of the effect of the coastal embankment programme because (i) the flooding

67 processes are complex and derive from many sources and (ii) it is difficult to establish what

68 the extent and severity of flooding might have been had the coastal embankments not been

69 constructed. This paper seeks to address both of these challenges by (i) analysing past events

70 to diagnose different types flooding and (ii) estimating the extent of flooding that could have

71 occurred had the polders not been constructed. The first challenge is addressed through

72 empirical analysis of the hydrometeorological factors that can explain the severity of

73 observed floods, whilst the second is tackled by constructing models of different types of

74 flooding. 


\section{2. Materials and methods}

This research was conducted in two stages (Fig. 2). First, a series of flood observations for the years 1988-2012 were obtained from remote sensing imagery. Records of rainfall, river water level, and surge levels for the same period were used to identify the main type of flooding for each observed event. Second, the counter-factual scenario without the construction of coastal embankments was modelled in order to hypothesise how the

81 flooding might have been different without the polders.

\subsection{Flood hazard of south western coastal region of Bangladesh}

The study addresses the south western coastal region of Bangladesh (Fig. 1) which is

84 vulnerable to fluvio-tidal flooding, monsoonal precipitation induced pluvial flooding, and 85 storm surges (Bhuiyan and Dutta, 2012; Gain et al., 2017). In the dry season, tidal oscillations

86 dominate the low flows in the river channel in this region, making it susceptible to salt water 87 intrusion. Before polder construction, a common practice from local people was to build 88 temporary earthen embankments in the dry season to protect the land from salinity and 89 remove those in wet season to enable sedimentation. Starting in 1960 a total of 44 polders

90 were built in the Coastal Embankment Project (CEP) (Nowreen et al., 2014; Paul and Rashid, 91 2017), protecting $5187 \mathrm{~km}^{2}$ (WARPO, 2018). Polder construction transformed the coastal 92 region into an agriculturally productive zone and encouraged people to settle within the 93 polders (Nowreen et al., 2014). Conversely, polder construction de-linked the floodplain 94 (Talchabhadel et al., 2016) and induced several problems including river flow reduction, 95 siltation in tidal channels, drainage congestion, waterlogging, land subsidence, polder 96 breaching, soil salinity, etc. (Auerbach et al., 2015; Choudhury et al., 2004; Gain et al., 2017;

97 Nowreen et al., 2014; Paul and Rashid, 2017). For instance, polder construction has resulted 98 in $1.0-1.5 \mathrm{~m}$ of land subsidence inside an embanked area (Polder 32), whereas the outside of 
99 this embankment, the neighbouring Sundarban mangrove forest, has remained comparatively 100 unchanged (Auerbach et al., 2015).

101 In response to multifaceted problems related to polders, over the years the 102 government of Bangladesh, in cooperation with various international donor agencies, have 103 implemented several projects. The World Bank, who supported the CEP project, has started

104 the Coastal Embankment Improvement Project (CEIP) Phase I in 2015, which is 105 rehabilitating and/or reconstructing several polders, as well as upgrading the drainage 106 channels and structures (Paul and Rashid, 2017). Meanwhile, the Blue Gold project, funded 107 by Government of the Netherlands (GoN) and operated by the Bangladesh Water 108 Development Board (BWDB), has been responsible for rehabilitation of water control 109 structures within 26 polders districts (http://www.bluegoldbd.org/). In addition, Tidal River 110 Management (TRM) has been adopted in an attempt to restore sedimentation within the 111 polders through selective flooding (Van Staveren et al., 2017), gaining attention as a potential 112 alternative to structural flood protection (Gain et al., 2017). The idea of TRM is to allow river 113 flow into low-lying bowl-shaped depressions (termed as 'Beel') within polder for sediment 114 deposition to fill those depressions (Masud et al., 2018; Van Staveren et al., 2017). Though 115 historically a community driven approach, BWDB implemented TRM in several 'Beels' in 116 1991-2013 (Masud et al., 2018).

117 Despite several initiatives, the challenges of providing sustainable flood risk management in 118 the south western polder region are intensifying, with the threat of sea level rise, upstream 119 modification of river flows and sediments from the Ganges Brahmaputra Meghna river 120 system, and high population density providing little space for adaptation (Haque et al., 2018; 121 Kay et al., 2018). 


\subsection{Identifying flood events}

In last two decades (Hoque et al., 2011), water surface detection through remote sensing techniques has become an essential tool for various disciplines (Sanyal and $\mathrm{Lu}, 2004$; Sarp and Ozcelik, 2017). Among various methods, water-indexing techniques have proved to be very useful for quick flood detection (Sarp and Ozcelik, 2017). This study applied the Modified Normalized Difference Water Index (MNDWI) (Xu, 2006) using ArcGIS 10.6.1 to detect water surfaces during pre (dry) and post (wet) monsoon period in a year. MNDWI uses green and middle infrared (MIR) bands of Landsat satellite images. It generates positive values for water surfaces and negative values for built-up areas, soil surfaces and vegetation. Then a change detection algorithm was used in Geographic Information System (GIS) to identify cells that changed from being normally dry to wet, which were classified as flood cells for that year. Cloud cover during the monsoon period (May to September) (Ahmed and Akter, 2017) meant that the analysis was applied to compare pre and post monsoon images. The image database is summarised in Table S2 of the Supplementary Information.

The major cyclone Sidr in 2007 caused prolonged flooding within the polders (Tareq et al., 2018), which lasted into 2008. Hence using pre-monsoon images of 2008 could cause under estimation of flood extent in 2008, so dry season images from 2007 we employed to detect flood extent in both 2007 and 2008.

The accuracy of MNDWI based classified images was assessed, for three different years $(1989,2001$, and 2010), against reference land cover data (classified and validated images) collected from Mukhopadhyay et al. (2018) (Table S1, supplementary document), producing an error matrix to estimate the overall accuracy and kappa statistics. The overall accuracy depicts a percentage agreement of pixels correctly classified (Lillesand et al., 2014). The kappa statistics $(\kappa)$ is a measure for inter-rater reliability testing, whose value can range from -1 to +1 , where 'values $\leq 0$ as indicating no agreement and $0.01-0.20$ as none to slight, 
$147 \quad 0.21-0.40$ as fair, $0.41-0.60$ as moderate, $0.61-0.80$ as substantial, and $0.81-1.00$ as almost 148 perfect agreement' (McHugh, 2012). The reference land cover data were converted into

149 binary images (water, dry) and classified dry season (pre-monsoon) images of those three

150 years were employed to estimate the indices of classification consistency. In this study,

151 'substantial agreement' within pixels between reference and classified land cover images

152 were found for 1989 and 2010, and 'almost perfect agreement' was achieved for 2001 image

153 classification (Table S3, supplementary document). The processed flood maps were used to 154 estimate the severity of observed flooding and also to validate the flood simulation outputs in 155 the second phase of the study. The reference land cover maps included 12 land use classes, in 156 which general waterbodies are separated from aquaculture, mixed agriculture/aquaculture and 157 agricultural lands. These maps were further used to analyse the types of land uses exposed to 158 pluvial flooding.

$159 \quad$ 2.3. Flood event classification

160 To attribute the observed floods to different sources of flooding, we analysed the 161 severity of monsoon rainfall and elevated water levels within the region. Extreme value 162 analysis was conducted by fitting to a generalized extreme-value (GEV) distribution using the 163 L-moment method (Coles et al., 2001; Gilleland and Katz, 2016). The cumulative distribution 164 function of the GEV distribution is:

$$
\mathrm{G}(\mathrm{z})=\exp \left[-\left\{1+\varepsilon\left(\frac{\mathrm{z}-\mu}{\sigma}\right)\right\}_{+1}^{-1 / \varepsilon}\right]
$$

165 Where, $z$ is the random variable (monsoon precipitation/peak river water level/peak 166 surge level) and $\varepsilon, \mu$, and $\sigma$ are the shape, location, and scale parameters respectively. The 167 return period (T) was estimated by following formula:

$$
\mathrm{T}=\frac{1}{1-\mathrm{G}(\mathrm{z})}
$$

The precipitation frequency analysis was based on 10-days gridded precipitation data 169 from the Bangladesh Meteorological Department, aggregated into yearly monsoonal total 
precipitation and computed the regional average from 1948-2012. Fluvio-tidal flood

171 attribution was based on annual peak water level (Rao and Hamed, 2000), averaged across 18

172 river gauges. Finally, tidal surges were identified though analysis of peak tidal water level

173 averaged across two tidal gauges in the Bay of Bengal, i.e. Hiron point and Khepupara (Fig.

174 1). Data used for flood frequency analysis are summarised in Table S1 of supplementary

175 document.

176 In each year the return period of pluvial rainfall, fluvio-tidal water level and surge 177 water level were estimated according to Equation 2, denoted $T_{p}, T_{f}$ and $T_{s}$, respectively. We 178 then sought to classify each year, estimating thresholds $T_{p}{ }^{\prime}, T_{f}{ }^{\prime}$ and $T_{s}{ }^{\prime}$ above which a flood 179 of the given type was said to have occurred and a flooded area $A_{f}^{\prime}$ which represented the 180 threshold between 'flood' and 'non-flood' events. The thresholds were optimised according 181 to the following criteria, applied in this order of priority:

182 1. The separation between 'flood' and 'non-flood' events should not be contradictory 183 i.e. events cannot be classified as being a version of 'flood' (i.e. pluvial, fluviotidal or surge) and 'non-flood'.

2. If an event with multiple types flood is identified, the classification of flood event

192 minimised. 


\subsection{Modelling flood events}

\subsubsection{Pluvial flood model}

To simulate the effect of polders on pluvial flood severity, a simple pluvial flood rainfall-runoff and spreading model was established. The model was then adjusted to simulate the effects of subsidence and drainage system.

Pluvial flooding materialises based on the interaction between precipitation, evapotranspiration, surface flow, local topography and drainage. It can occur either due to intense downpours (Falconer et al., 2009; Houston et al., 2011) or by prolonged moderate to heavy rainfall (Falconer et al., 2009). In low-lying areas like the polder region of south western Bangladesh, these processes are extremely complex, so we have developed simplified GIS-based water balance and flood spreading model to estimate inundated areas.

The Thornthwaite and Mather (TM) water balance model was used to produce monthly excess precipitation grids. The water balance model takes gridded monthly total precipitation $(P)$, monthly mean temperature, monthly mean daylight hours, soil texture to estimate monthly potential evapotranspiration (equation 3), monthly water deficit or excess precipitation, actual evapotranspiration (equation 4, 5, 6, 7), and excess precipitation (equation 8, 9, 10). Raster layers of potential evapotranspiration (PE) and monthly water deficit or surplus (P-PE) in mm were calculated as follows:

$$
P E_{m}=16 C\left(10 \frac{T}{I}\right)^{a}
$$

Where, $T$ is the monthly average temperature $\left({ }^{\circ} \mathrm{C}\right), I$ is the annual heat index for the year in concern, calculated as $I=\sum_{1}^{12} i$, where the monthly heat index $i=[T / 5]^{1.514}, a=$ $6.75 \times 10^{-7} I^{3}-7.71 \times 10^{-5} I^{2}+1.792 \times 10^{-2} I+0.49239 ;$ the correction factor $C=m / 30 . d / 12$, where $m$ is the number of days in the month and $d$ is the monthly mean daylight hours (Singh et al., 2004). The estimated monthly PE was then subtracted from the monthly $P$ to find out the water excess $(+)$ or deficit (-). After that, the soil budget was estimated to find the actual 
217 evapotranspiration. At this stage, a raster layer of available water capacity $\left(\mathrm{SOIL}_{\max }\right)$ was 218 created following Thornthwaite and Mather (1957) principles. As Dingman (2002)

219 demonstrated,

$$
\begin{gathered}
\text { If } \mathrm{P}_{\mathrm{m}} \geq \mathrm{PE}_{\mathrm{m}} \quad \begin{array}{c}
\text { SOI } L_{m}=\min \left\{\left[\left(P_{m}-P E_{m}\right)+S O I L_{m-1}\right], S O I L_{\max }\right\} \\
A E T_{m}=P E_{m}
\end{array} \\
\text { If } \mathrm{P}_{\mathrm{m}}<\mathrm{PE}_{\mathrm{m}}, \quad \\
S O I L_{m}=S O I L_{m-1}\left[\exp \left(\frac{P_{m}-P E_{m}}{S O I L_{\text {max }}}\right)\right] \\
A E T_{m}=P_{m}+S O I L_{m-1}-S O I L_{m}
\end{gathered}
$$

Where, $\mathrm{AET}_{\mathrm{m}}$ is the actual evapotranspiration of the month in concern; $\mathrm{SOIL}_{\mathrm{m}-1}$ is the soil moisture content of previous month. To solve this recursive equation, the GIS toolset started running from the first month (when $\mathrm{P}-\mathrm{PE}<0$ ) after the monsoon, considering that the soil moisture storage in previous month (last month of monsoon) was full, i.e. equal to the 224 estimated available water capacity. Next, the following conditions and equations were 225 followed to estimate the monthly and monsoonal total excess precipitation (SUR).

If $(\mathrm{P}-\mathrm{PE})_{\mathrm{m}}<0$,

If $(\mathrm{P}-\mathrm{PE})_{\mathrm{m}} \geq 0$ and $\mathrm{SOIL}_{\mathrm{m}}=\mathrm{SOIL}_{\max }$,

If $(\mathrm{P}-\mathrm{PE})_{\mathrm{m}} \geq 0$ and $\mathrm{SOIL}_{\mathrm{m}} \neq \mathrm{SOIL}_{\max }$,

Monsoon total excess precipitation,

$$
\begin{gathered}
\operatorname{SUR}_{\mathrm{m}}=0 \\
\operatorname{SUR}_{\mathrm{m}}=(\mathrm{P}-\mathrm{PE})_{\mathrm{m}} \\
\mathrm{SUR}_{\mathrm{m}}=(\mathrm{P}-\mathrm{AET})_{\mathrm{m}}+\mathrm{SOIL}_{\mathrm{m}} \\
\mathrm{SUR}_{\mathrm{Y}}=\sum \mathrm{SUR}_{\text {May to September }}
\end{gathered}
$$

The flood extent was estimated by considering a series of surface depressions, whose catchments are nested (Diaz-Nieto et al., 2011). The SRTM DEM was analysed to identify surface depressions, their exit points (points through which water will pass to next level depressions when a depression is full), and catchment areas. While identifying exit points, the model followed the single-direction flow algorithm (D8), where one cell routed into the next

231 steepest of eight neighbouring cells (Seibert and McGlynn, 2007), and eliminated cells which 232 drained back to the same depression. After that it selected depression points to define 233 respective depressions catchments and nest levels were assigned for depression catchments. 
234 The total volume of monsoon excess water from the water balance model was assigned to 235 each depression. The water accumulation algorithm (equation 12) was started from the 236 highest nest level depressions to accumulate water and subsequently passes to next level 237 depressions. At this point, the model routes additional water, after filling previous level 238 depressions (if remains), to the existing catchment(s). This iterative process continued until 239 the model distributed water to the lowest nest level (Diaz-Nieto et al., 2011):

$$
\mathrm{P}_{\mathrm{P}=0 \rightarrow \mathrm{P}<0}=\sum \mathrm{P}_{\mathrm{j}=1, \mathrm{n}}+\mathrm{E}-\mathrm{V}
$$

240 Where, $P=$ water volume passed down from depression, $E=$ access volume after 241 filling the depression, $V=$ depression volume, $j=$ counter of nested depressions from 1 to $n$.

242 For each year (1988-2012), the model was used to simulate pluvial inundation with and 243 without polders. For pluvial inundation 'with' polders the observed DEM was used. Drainage 244 from the polder was constrained due to inadequate maintenance of drainage channels and 245 deterioration of sluice gates.

246 Brown and Nicholls (2015) documented 205 points measurements of net subsidence.

247 Yearly land subsidence rates used in this study ranging from $0.24 \mathrm{~mm}$ to $10 \mathrm{~mm}$ per year.

248 Using these point measurements, a raster of yearly subsidence rate was created, using Inverse

249 Distance Weighted (IDW) interpolation. Multiplying this raster with subsequent number of 250 years starting from 1960 (commencing year of polder construction) was added to the existing 251 DEM to reconstruct past land elevations. The reconstructed DEM was used to delineate 252 potential flood locations (surface depressions) in the 'without' polder scenario. The estimated 253 total excess precipitation in each year was accumulated in the depressions and nested 254 catchments. We further developed a scenario in which drainage channels within the polders 255 were effectively maintained. These channels were identified by hand from the satellite image. 256 Catchments that contained these channels were permitted to drain. 
We performed sensitivity analyses for (a) the method used to interpolate land

258 subsidence rate (b) the rate of land subsidence, which was used to establish pluvial flood 259 model for the counterfactual scenario. First, using the observed land subsidence data we 260 generated three additional layers of land subsidence rates, applying kriging, spline, and 261 natural neighbour methods in GIS (Childs, 2004). These layers were incorporated to generate 262 pluvial flood inundation simulations for the 25 years studied for the counterfactual scenario. 263 We tested for significant differences in annual pluvial inundation in the counterfactual 264 scenario (Figure S1, supplementary document). This was done applying one-way analysis of 265 variance (ANOVA) test. An ANOVA test could be performed to measure the sensitivity of 266 input parameters (e.g. DEM) in hydraulic modelling and floodplain mapping (Raber et al., 267 2007). The estimated $p$-value 0.22 indicated that the difference in inundation for four types of 268 land subsidence rates is not significant. The insignificant p-value and a smaller value of F269 ratio than the critical F-ratio (Table S4, supplementary document) confirmed the absence of 270 sensitivity in the pluvial flood model in relation to method applied to interpolate the rate of 271 land subsidence.

272 In addition, we generated raster layers of two land subsidence rates, randomly 273 splitting the observed 205 points measurements of net subsidence rate into two groups. The 274 first group contained a subset of $70 \%$ points, whereas the second group was comprised of the 275 remaining $30 \%$ points. Yearly land subsidence rates in the two groups ranging from $1 \mathrm{~mm}$ to $27610 \mathrm{~mm}$ and $1 \mathrm{~mm}$ to $6 \mathrm{~mm}$, respectively. We applied IDW interpolation method to obtain two 277 layers of subsidence rates, which were added (multiplying by the difference of modelled year 278 from 1960) separately on the existing DEM to generate two different surfaces. We 279 incorporated these surfaces in pluvial flood model to estimate the inundated area across 280 delineated depressions. Here, we modelled the pluvial events of 2004 and 2006, when a 281 higher amount of excess precipitation was estimated (Fig. 6). Figure S2 in supplementary 
document exhibits a similar pattern of individual depression behaviour for a change in land subsidence rate. Again, ANOVA test was performed to analyse the difference in inundation during two events in individual depression, for different rates of land subsidence. The obtained p-value 0.27 and F-ratio $1.3(<$ critical F-ratio 2.01) indicated that the difference in inundation in different depressions insignificant.

The pluvial flood model was validated based on a field survey that was conducted on May 2018 to collect GPS locations of pluvial floods and non-floods (Figure S3, supplementary document). An error matrix was produced (Table S5, supplementary document) to verify the accuracy of modelled potential flood/non-flood pixels, comparing to observations. An overall accuracy of $95 \%$ and spatial statistical $\kappa$ statistics value 0.87 suggest an 'almost perfect agreement' (McHugh, 2012) between observed and modelled flood pixels.

The observed total inundation in years that were identified as pluvial flood events were plotted against the modelled inundation of corresponding years for 'with polder' scenario, yielding a coefficient of determination $\mathrm{R}^{2}=0.98$ (Fig. 3). However, the validation process also included 2005 event, despite it was classified as 'no flood' event. The reason for using this event to validate the pluvial flood model is explained in Section 3.3.

\subsubsection{Fluvio-tidal and storm surge inundation model}

The Delft 3D hydrodynamic model (Haque et al., 2018) was used to estimate

300 inundation extent from fluvio-tidal (1998) and storm surge flooding (2007) for 'with' and

301 'without' polder scenarios. The model domain was bounded by border with India in the west 302 (type of boundary is not fixed), Lower Meghna estuary in the east, three major rivers 303 (Ganges, Brahmaputra and Upper Meghna) in the north and Bay of Bengal in the south. The 304 discretized model domain contains 896,603 grid points, where grid size varies from $186 \mathrm{~m}$ to $3051704 \mathrm{~m}$. Coarser grid size is provided in the ocean and finer grid size is provided in the river 306 channels to capture the details of the river/estuarine systems and topographic variation. The 
model was set up for all rivers and estuaries with a width of at least $100 \mathrm{~m}$. Measured flow data was provided from BWDB for three the major rivers, from which fluvial flow enters the model. In absence of measured sea level data, the model takes simulated sea level data from

310 the GCOMS model (Kay et al., 2015), which generated the tidal (ocean) boundary. As 311 morphological changes were considered static (except subsidence) - no additional sediment 312 input is provided. A rate of $2.6 \mathrm{~mm} / \mathrm{yr}$ (Brown and Nicholls, 2015) of subsidence is 313 considered in the area bounded by the polders including the polder itself. A DEM with a 314 spatial resolution of 50m was provided by WARPO (2018). The ocean bathymetry data was 315 obtained from General Bathymetric Chart of the Oceans (GEBCO) while river bathymetry 316 data was collected from BWDB at 294 locations in coastal rivers/estuaries. Channel 317 planforms were assumed to remain the same over the model simulation period. Similar 318 assumption was made for channel bed level and floodplain levels of rivers / estuaries.

319 The model indirectly considered impacts of land use and land cover through 320 resistance in the floodplain. Different resistance values were specified for sea, 321 rivers/estuaries, floodplain and forest (Sundarban). These resistance values were determined 322 during model calibration. The calibrated Manning's roughness coefficient was spatially 323 variable having values of 0.00025 in the ocean (considered as large water body), 0.015 to 3240.025 in rivers /estuaries (a value generally considered to be valid for rivers / estuaries in the 325 region), 0.025 to 0.040 in the floodplain, and 0.08 to 0.1 in forests including mangrove and 326 natural plantation. The model simulated 103 polder areas (out of 139) using design heights of 327 embankments collected from BWDB. Present day observations are only available for 61 328 polders (some of which are outside the study region) that show that actual polder heights can vary from $3 \mathrm{~m}$ to $7 \mathrm{~m}$ (Huq et al., 2010). Where actual embankment heights are not available, 330 an average design embankment height of $4.75 \mathrm{~m}$ is used in the model (CEIP, 2013). Storm 331 surge modelling was based on a reconstructed cyclone track for the 2007 cyclone Sidr (Figure 
332 S4, supplementary document) that passed by the study area. Consideration of reconstructed

333 cyclone track was based on the premise that modelled result could ideally explain the

334 observed flood inundation. Resulting simulated inundation data was masked for the south

335 western polder region. Further details on model setup, calibration, and validation can be

336 found in Haque et al. (2018) and Haque and Rahman (2016).

\section{3. Results and discussion}

\subsection{Identification of flood events}

In 25 observed years, the inundated area ranged from 6\% (in 2010) to 48\% (in 2001).

340 The mean flood footprint was $13 \%$ of the total embanked region. The patterns of inundation 341 were heterogeneous spatially and temporally, with different parts of the embanked region

342 flooded in different years. Six polders were flooded by more than $13 \%$ (average flood area)

343 of their respective area, on average. The largest extent of inundation occurred in polder 34/1,

344 whereas the polder $28 / 2$ and 30 experienced the lowest level of inundation (Figure S5, 345 supplementary document).

346 Fig. 7(a) shows a typical inundation footprint for the year 2004 obtained from remote 347 sensing data analysis. Here, major inundation occurred in the northern segment of embanked 348 region. Generally, flooding in the south western part of the region was less frequent and the 349 extent of inundation in that segment was relatively low during various events.

\section{$350 \quad$ 3.2. Classification of flood events}

level, and peak surge level respectively to classify them into pluvial, fluvio-tidal, and surge

354 induced floods. The estimated return periods of these three hydrological parameters varied 355 annually, indicating different types of floods in different years. For instance, within 25

356 observed years, the highest monsoon precipitation was in 2002, whereas the highest peak 
river water level and surge level were in 1996 and 2007 respectively. The relationship between flood conditioning factors and flood type is complex (Nied et al., 2014), in this study, we provide a simplified flood classification system estimating minimum thresholds $T_{p}{ }^{\prime}, T_{f}^{\prime}$ and $T_{s}{ }^{\prime}$.

\subsubsection{Flood event classification}

Table 1 presents the return period of each type of flood in each year. The optimisation

363 of return periods of three hydrological parameters yielded the following minimum flood 364 thresholds: $T_{p}{ }^{\prime}=5.2$ years, $T_{f}{ }^{\prime}=5.9$ years and $T_{s}{ }^{\prime}=7.9$ years and threshold between 'flood' 365 and 'non-flood' events was $10.3 \%$ of the area. According to this criterion, floods were 366 identified as occurring in 14 different years and three compound events were detected. The 367 estimated thresholds generated one false negative and one false positive flood event. The 368 event in 1996 was classified as ' $\mathrm{F}$ ' even though the flood area was $9.2 \%$. The highest $T_{f}$ 369 during that event was responsible for such attribution. Besides, 2005 event was classified as 370 ' $\mathrm{N}$ ' despite about $11.5 \%$ area was inundated. In 2005 , the region received a lower level of monsoon precipitation, in addition to low peak river water level and surge level. The outcome of pluvial flood model explained the reason for a higher level of inundation in 2005 (Section $3734.3)$

We find that pluvial flooding was the most frequent, but typically resulted in less

375 flooded area (11.4\% of the region on average) compared with the other forms of flooding.

376 The fluvio-tidal and surge induced floods caused more extensive inundation than the pluvial 377 floods: $21.8 \%$ and $30.2 \%$ on average, respectively. The greatest area of inundation (48\% of 378 total area) occurring in 2001 as a consequence of fluvio-tidal and surge flooding, whilst cyclone Sidr in 2007 flooded $35 \%$ of the area.

Fig. 5(a) illustrates the identified pluvial floods. We classified seven pluvial flood 
received the highest monsoonal precipitation of $1861.91 \mathrm{~mm}$ in 2002 leading to an 18.8-year return level of pluvial flood. The highest two precipitation events in 2002 and 2011 caused approximately $11 \%$ of total polder area inundation, while 2004 resulted in the highest pluvial inundation (13\% area).

The six events that were classified as fluvio-tidal happened in 1995, 1996, 1998, 2000,2001 , and 2002. The highest regional average peak water level of $3.45 \mathrm{~m}$ was observed in 1996, leading to a 34.6-year event (Fig. 5(b)). But the most extreme event did not result in the highest extent of inundation. For instance, whilst in 1996 the inundation area was $9 \%$, the highest percentage of total area (48\%) was inundated in 2001 when the region experienced a

391 23-year fluvio-tidal flood which breached various polders. However, the 2001 event was 392 attributed to both the fluvio-tidal and surge event, though fluvio-tidal flood was the dominant

393 force (as higher return period) leading to the inundation. Fluvio-tidal floods mostly occurred 394 in between 1995 and 2002. After 2003, relatively a lower mean discharge in upper Ganges 395 River was observed (Figure S6, supplementary document), contributing to a lower peak river water level.

Four surge induced floods were attributed, considering the estimated 7.9-year return period as minimum threshold limit (Fig. 5(c)). The most extreme surge occurred in 2007

399 during the cyclone Sidr, when the peak surge height reached to $4.16 \mathrm{~m}$ (35-year return 400 period), causing $35 \%$ of the total area inundation. Another major cyclone Aila affected the 401 study area in 2009 with a peak surge of $4.10 \mathrm{~m}$, leading to $21 \%$ area inundation. Both fluvio402 tidal and surge flooding formed the compound event of 1995, when the impact of surge was 403 the highest.

\subsection{Modelling flood inundation with and without polders}


studied years (Fig. 6). The extent of inundation has a strong positive correlation with the amount of excess precipitation (correlation coefficient $=0.90$ ). Among the classified seven

409 pluvial flood events (Table 1), the lowest level of monsoon precipitation was observed in 410 2004. But, the greatest extent of pluvial inundation was estimated in 2004, due to presence of 411 the highest amount of excess precipitation caused by a lower level of evapotranspiration. In 412 2005, the modelled pluvial inundation was $11.2 \%$ area, which is similar to observed flood 413 inundation (11.5\%) for that year. The lowest level of evapotranspiration was estimated in 4142005 , leading to a higher amount of excess precipitation. Therefore, the extent of inundation 415 in 2005 was greater than $A_{f}^{\prime}(10.3 \%)$, despite the region received a 1.2-year return level 416 precipitation. Thus, we included this event to validate the outcome of pluvial flood modelling 417 (Section 2.4.1). The results from pluvial flood modelling further demonstrated that a greater 418 extent of inundation was the outcome of polder construction and inadequate drainage 419 systems. The extent of pluvial inundation would have been substantially lower in absence of 420 polders.

421 Typical results from the pluvial flood model are shown in Fig. 7(b, c), which 422 illustrates how a combination of land subsidence (a maximum of approximately $0.5 \mathrm{~m}$ relative 423 to locations where polders were not constructed) and inadequate drainage, has exacerbated 424 pluvial flooding. We estimate that on average over the modelled period the extent of flooded 425 area was $334 \mathrm{~km}^{2}$ (i.e. $6.5 \%$ of total area) larger because of the land subsidence, generated 426 from the construction of polders, and inadequate drainage. The extent of inundation primarily 427 depends on the number of surface depressions generated due to land subsidence. Polder 428 construction increased the number of shallow depressions $(<1 \mathrm{~m}$ in depth), which are prone to 429 flooding. Without polders flooding in those areas might have been alleviated, as 430 sedimentation would have transformed the geomorphology of the region and reduced the 431 number of shallow depressions. Flooding in that case would have only occurred in areas 
432 characterized as deep surface depressions. Hence, our modelled pluvial inundation for the 433 counter-factual scenario showed relatively a small year-to-year difference in the extent of 434 inundation (Fig. 6), although the total inundated area was positively correlated with the 435 estimated excess precipitation.

436 Results from the pluvial flood model further indicated that if the observed drainage 437 system were maintained adequately, it would have been able to reduce pluvial flooding by 438 about $4.9 \%$. This number is relatively small because there are many catchments that were not 439 observed to have a drainage channel. The pluvial flood prone area comprises about $50 \%$ 440 aquaculture land (shrimp culture and freshwater fish culture), which is not necessarily 441 harmfully affected by flooding. However, $40 \%$ of the flood-prone area is agricultural land 442 (rice field, other croplands, mixed rice and shrimp culture) which can be more adversely 443 impacted by pluvial flooding, whilst $10 \%$ is comprised of settlement areas with homestead 444 vegetation where pluvial flooding is directly harmful.

445 Simulations of fluvio-tidal and surge flooding demonstrate the effectiveness of 446 embankments in reducing inundation due to elevated water levels. For example, during the 4471998 fluvio-tidal flood, majority of the region would have been flooded without polders. The 448 presence of polders resulted in an estimated $27 \%$ of total area being flooded in this fluvio449 tidal flood, compared to $79 \%$ for the 'without polder' counter-factual. Complete inundation 450 occurred in 14 polders for 'with' polder scenario, which would have been escalated to 31 451 polders for the counter-factual scenario (Fig. 8(a)). Overlaying the inundated areas for both 452 scenarios, we found that the embankments protected an estimated 54\% area from flooding.

453 Simulation results for surge event Sidr suggests that, in presence of polders (without 454 breaching), about $18 \%$ of the total area might have been inundated. Without polders, the 455 extent of inundation would have been increased to approximately $35 \%$ area. Seventeen 456 different polders that were partially at risk of flooding would have been inundated by more 
than $80 \%$ area without embankments (Fig. 8(b)). However, our modelled total inundation for

458 counter-factual scenario is similar to the observed inundation of $35 \%$ area. When simulating

459 inundation for 'with polder' scenario, the model considered overtopping as the flood

460 mechanism in polders. Therefore, the number of flood-affected polders were substantially

461 lower under this scenario. But, embankment failure in several polders, both in form of

462 damage and overtopping, increased the extent of inundation. Furthermore, the observed

463 inundation in 2007 is a compound inundation of pluvial and surge induced flooding. The

464 estimated pluvial inundation in 2007 was about $10 \%$ area. Subtracting (spatially) the pluvial

465 inundation from the observed inundation, we found that surge induced flood solely

466 contributed to the inundation in $25 \%$ area.

\section{4. Conclusion}

468 Creation of polders by construction of embankments in coastal Bangladesh has been a 469 controversial process. The creation of polders enabled large increases in agricultural 470 production and reduced the impacts of storm surges and fluvio-tidal floods. However, 471 blocking off the coastal floodplain from channels practically eliminated annual deposition of 472 sediments on the land, whilst compaction of sediment and anthropogenic activities 473 exacerbated land subsidence. Over the years, drainage channels have not been adequately 474 maintained, which has inhibited drainage of pluvial flood waters and exacerbated 475 inundations. Moreover, construction of polders has provided an impression of security from 476 flood hazards, encouraging human settlement in vulnerable locations.

477 In this paper we have empirically analysed the evidence for both the beneficial and 478 harmful impacts of polder construction. We found that pluvial flooding occurs frequently, but 479 the flood extent is usually less than in other forms of flooding. By modelling a counter480 factual scenario in which polders had not been constructed we quantified a substantial (6.5\% 
area) increase in pluvial flooding that can be attributed to land subsidence resulted from polder construction and poor management of drainage facilities.

On the other hand, the polders have provided protection against fluvio-tidal and storm surge events. In the worst fluvio-tidal flood in the 'without polder' scenario $79 \%$ of the area would have been flooded, compared with $27 \%$ which occurred with the polders. In the surge event Sidr, $18 \%$ of the polder area would have been flooded, without the breaching to embankments. But, the extent of inundation was increased to $25 \%$ area due to the damage to embankments during the cyclone. Simultaneously, pluvial flooding exacerbated the flood impact, inundating a total $35 \%$ area in 2007.

The empirical analysis of past floods reported in this paper is subject to errors in 491 observations of precipitation and water levels. In addition, the recognition of flooded areas 492 from satellite imagery is also subject to error. The attribution of flood types is to some extent 493 subjective, based on the criteria that were used to optimise the classification thresholds. 494 Given the relatively short record of flood events, the complexity of the flooding process and 495 the possibility of compound events, it would not be possible to establish a definitive 496 classification method.

Flooding processes in low-lying coastal areas are complex, so the modelling we have used to analyse the 'without polder' counter-factual is inevitably approximate. This 499 particularly applies to pluvial flooding, which is sensitivity to local rainfall patterns, 500 topography, land surface and drainage and so would be extremely difficult to model with 501 more accuracy on the spatial/temporal scale considered in this study. Nonetheless, these 502 models have provided insights into the polders' effectiveness. Generally, this study is an 503 attempt to estimate the impact of anthropogenic intervention (creation of coastal 504 embankments) on the hydrology (inundation) of south western embanked region of 505 Bangladesh. 
Rehabilitation and reconstruction of embankments is now under way in the coastal zone of Bangladesh (Figure S8, supplementary document). Further choices will need to be

508 made in the face of rising sea levels. Alternative adaptation strategies are being examined as 509 part of the Bangladesh Delta Plan. The empirical analysis of the benefits and impacts of 510 embankment construction, which has been reported in this paper, should help to inform plans 511 for adaptation of Bangladesh's coastal zone to flood hazards, by helping to target and 512 sequence investments for flood management.

\section{$513 \quad$ Acknowledgement}

514 This work is an output from the REACH programme (www.reachwater.org.uk) 515 funded by UK Aid from the UK Department for International Development (DFID) for the 516 benefit of developing countries (Aries Code 201880). However, the views expressed, and 517 information contained in it are not necessarily those of or endorsed by DFID, which can 518 accept no responsibility for such views or information or for any reliance placed on them. We 519 thank the anonymous reviewers for their careful reading of our manuscript and insightful 520 comments and suggestions.

\section{5. References}

522 Abdullah AYM, Masrur A, Adnan MSG, Baky MAA, Hassan QK, Dewan A. Spatio523 Temporal Patterns of Land Use/Land Cover Change in the Heterogeneous Coastal Region of Bangladesh between 1990 and 2017. Remote Sensing 2019; 11: 790.

Abedin MA, Shaw R. The role of university networks in disaster risk reduction: Perspective from coastal Bangladesh. International Journal of Disaster Risk Reduction 2015; 13:

528 Ahmed KR, Akter S. Analysis of landcover change in southwest Bengal delta due to floods 529 by NDVI, NDWI and K-means cluster with landsat multi-spectral surface reflectance 
satellite data. Remote Sensing Applications: Society and Environment 2017; 8: 168181.

Akber MA, Khan MWR, Islam MA, Rahman MM, Rahman MR. Impact of land use change on ecosystem services of southwest coastal Bangladesh. Journal of Land Use Science

Brown S, Nicholls RJ. Subsidence and human influences in mega deltas: The case of the 553 $2018 ; 13: 238-250$.

Alam MS, Sasaki N, Datta A. Waterlogging, crop damage and adaptation interventions in the coastal region of Bangladesh: A perception analysis of local people. Environmental Development 2017; 23: 22-32.

Auerbach LW, Goodbred SL, Jr., Mondal DR, Wilson CA, Ahmed KR, Roy K, et al. Flood risk of natural and embanked landscapes on the Ganges-Brahmaputra tidal delta plain. Nature Climate Change 2015; 5: 153-157.

Bamberg S, Masson T, Brewitt K, Nemetschek N. Threat, coping and flood prevention - A meta-analysis. Journal of Environmental Psychology 2017; 54: 116-126.

Bhuiyan MJAN, Dutta D. Analysis of flood vulnerability and assessment of the impacts in coastal zones of Bangladesh due to potential sea-level rise. Natural Hazards 2012; 61: 729-743.

Brammer H. Bangladesh's dynamic coastal regions and sea-level rise. Climate Risk Management 2014; 1: 51-62.

Brouwer R, Akter S, Brander L, Haque E. Socioeconomic Vulnerability and Adaptation to Environmental Risk: A Case Study of Climate Change and Flooding in Bangladesh. Risk Analysis 2007; 27: 313-326.

Ganges-Brahmaputra-Meghna. Science of The Total Environment 2015; 527-528: $362-374$. 
CEIP. Technical feasibility studies and detailed design for Coastal Embankment Improvement Programme (CEIP). Ministry of Water Resources, Government of the People's Republic of Bangladesh, Dhaka, 2013.

Childs C. Interpolating surfaces in ArcGIS spatial analyst. ArcUser, July-September 2004; 3235: 569.

Choudhury NY, Paul A, Paul BK. Impact of costal embankment on the flash flood in Bangladesh: A case study. Applied Geography 2004; 24: 241-258.

Coles S, Bawa J, Trenner L, Dorazio P. An introduction to statistical modeling of extreme values. Vol 208: Springer, 2001.

Diaz-Nieto J, Lerner DN, Saul AJ, Blanksby J. GIS Water-Balance Approach to Support Surface Water Flood-Risk Management. Journal of Hydrologic Engineering 2011; 17: $55-67$.

Dingman SL. Physical hydrology: Waveland Press, 2002.

Falconer R, Cobby D, Smyth P, Astle G, Dent J, Golding B. Pluvial flooding: new approaches in flood warning, mapping and risk management. Journal of Flood Risk Management 2009; 2: 198-208.

Gain AK, Benson D, Rahman R, Datta DK, Rouillard JJ. Tidal river management in the south west Ganges-Brahmaputra delta in Bangladesh: Moving towards a transdisciplinary approach? Environmental Science and Policy 2017; 75: 111-120.

Gilleland E, Katz RW. Extremes 2.0: an extreme value analysis package in r. Journal of Statistical Software 2016; 72: 1-39.

575 Haque A, Kay S, Nicholls RJ. Present and Future Fluvial, Tidal and Storm Surge Flooding in 576 Coastal Bangladesh. Ecosystem Services for Well-Being in Deltas. Springer, 2018, 577 pp. 293-314. 
Haque A, Nicholls RJ. Floods and the Ganges-Brahmaputra-Meghna Delta. Ecosystem Services for Well-Being in Deltas. Springer, 2018, pp. 147-159.

Haque A, Rahman M. Flow Distribution and Sediment Transport Mechanism in the Estuarine Systems of Ganges-Brahmaputra-Meghna Delta. International Journal of Environmental Science and Development 2016; 7: 22.

Hoque R, Nakayama D, Matsuyama H, Matsumoto J. Flood monitoring, mapping and assessing capabilities using RADARSAT remote sensing, GIS and ground data for Bangladesh. Natural Hazards 2011; 57: 525-548.

Houston D, Werritty A, Bassett D, Geddes A, Hoolachan A, McMillan M. Pluvial (rainrelated) flooding in urban areas: the invisible hazard. York: Joseph Rowntree Foundation 2011.

Hui R, Jachens E, Lund J. Risk-based planning analysis for a single levee. Water Resources Research 2016; 52: 2513-2528.

Huq M, Khan MF, Pandey K, Ahmed MMZ, Khan ZH, Dasgupta S, et al. Vulnerability of Bangladesh to cyclones in a changing climate: potential damages and adaptation cost: The World Bank, 2010.

Islam M, Kotani K, Managi S. Climate perception and flood mitigation cooperation: A Bangladesh case study. Economic Analysis and Policy 2016a; 49: 117-133.

Islam MA, Mitra D, Dewan A, Akhter SH. Coastal multi-hazard vulnerability assessment along the Ganges deltaic coast of BangladesheA geospatial approach. Ocean \& Coastal Management 2016b; 127: 1-15.

Kay S, Caesar J, Janes T. Marine Dynamics and Productivity in the Bay of Bengal. Ecosystem Services for Well-Being in Deltas. Springer, 2018, pp. 263-275.

Kay S, Caesar J, Wolf J, Bricheno L, Nicholls RJ, Saiful Islam AKM, et al. Modelling the increased frequency of extreme sea levels in the Ganges-Brahmaputra-Meghna delta 
due to sea level rise and other effects of climate change. Environmental Sciences: Processes and Impacts 2015; 17: 1311-1322.

Khan MMH, Bryceson I, Kolivras KN, Faruque F, Rahman MM, Haque U. Natural disasters and land-use/land-cover change in the southwest coastal areas of Bangladesh. Regional Environmental Change 2015; 15: 241-250.

Masud MMA, Moni NN, Azadi H, Van Passel S. Sustainability impacts of tidal river management: Towards a conceptual framework. Ecological Indicators 2018; 85: 451467.

McHugh ML. Interrater reliability: the kappa statistic. Biochemia Medica 2012; 22: 276-282.

614 Moniruzzaman M. Impact of Climate Change in Bangladesh: Water Logging at South-West 615 Coast. In: Leal Filho W, editor. Climate Change and the Sustainable Use of Water 616 Resources. Springer Berlin Heidelberg, Berlin, Heidelberg, 2012, pp. 317-336.

617 Mukhopadhyay A, Hornby DD, Hutton CW, Lázár AN, Amoako Johnson F, Ghosh T. Land Cover and Land Use Analysis in Coastal Bangladesh. In: Nicholls RJ, Hutton CW, Adger WN, Hanson SE, Rahman MM, Salehin M, editors. Ecosystem Services for Well-Being in Deltas: Integrated Assessment for Policy Analysis. Springer International Publishing, Cham, 2018, pp. 367-381.

Nied M, Pardowitz T, Nissen K, Ulbrich U, Hundecha Y, Merz B. On the relationship between hydro-meteorological patterns and flood types. Journal of Hydrology 2014;

625 Nishat A, Nishat B, Abdullah Khan MF. A Strategic View of Land Management Planning in 626 Bangladesh. Flood Risk Science and Management, 2010, pp. 484-498. 
627 Nowreen S, Jalal MR, Khan MSA. Historical analysis of rationalizing South West coastal 628 polders of Bangladesh. Water Policy 2014; 16: 264-279.

629 Paul BK, Rashid H. Climatic Hazards In Coastal Bangladesh - Non-Structural and Structural $630 \quad$ Solutions. Cambridge, United States: Elsevier, 2017.

631 Raber GT, Jensen JR, Hodgson ME, Tullis JA, Davis BA, Berglund J. Impact of LiDAR 632 nominal post-spacing on DEM accuracy and flood zone delineation. Photogrammetric 633 engineering \& remote sensing 2007; 73: 793-804.

634 Rahman R, Salehin M. Flood Risks and Reduction Approaches in Bangladesh. In: Shaw R, 635 Mallick F, Islam A, editors. Disaster Risk Reduction Approaches in Bangladesh. 636 Springer, Tokyo, 2013, pp. 65-90.

637 Rao AR, Hamed K. Flood frequency analysis. USA: CRC press, 2000.

638 Roy K, Gain AK, Mallick B, Vogt J. Social, hydro-ecological and climatic change in the southwest coastal region of Bangladesh. Regional Environmental Change 2017; 17:

Sanyal J, Lu XX. Application of remote sensing in flood management with special reference 1895-1906.

646 Seibert J, McGlynn BL. A new triangular multiple flow direction algorithm for computing upslope areas from gridded digital elevation models. Water Resources Research 2007; 43.

649 Singh RK, Hari Prasad V, Bhatt CM. Remote sensing and GIS approach for assessment of the 650 water balance of a watershed. Hydrological Sciences Journal 2004; 49: 131-142. 
651 Talchabhadel R, Nakagawa H, Kawaike K. Tidal River Management (TRM) and Tidal Basin Management (TBM): A case study on Bangladesh. E3S Web of Conferences. 7, 2016.

653 Tareq SM, Tauhid Ur Rahman M, Zahedul Islam AZM, Baddruzzaman ABM, Ashraf Ali M.

654 Evaluation of climate-induced waterlogging hazards in the south-west coast of 655 Bangladesh using Geoinformatics. Environmental Monitoring and Assessment 2018; $656 \quad 190: 230$.

657 Thornthwaite CW, Mather JR. Instructions and tables for computing potential 658 evapotranspiration and the water balance. Drexel Institute of Technology, Centerton, 659 NJ (EUA). Laboratory of Climatology, 1957.

660 Van Staveren MF, Warner JF, Khan MSA. Bringing in the tides. from closing down to 661 opening up delta polders via Tidal River Management in the southwest delta of

663 WARPO. National Water Resources Database(NWRD). Water Resources Planning 664 Organization (WARPO), Bangladesh, 2018.

$665 \mathrm{Xu} \mathrm{H}$. Modification of normalised difference water index (NDWI) to enhance open water 666 features in remotely sensed imagery. International Journal of Remote Sensing 2006;

667 27: 3025-3033. 
Table 1. Flood attribution in south western polder region

\begin{tabular}{|c|c|c|c|c|c|}
\hline Year & $\begin{array}{l}\text { Precipitation } \\
\text { return } \\
\text { period }\left(T_{p}\right)\end{array}$ & $\begin{array}{c}\text { Return period } \\
\text { of peak river } \\
\text { water level }\left(T_{f}\right)\end{array}$ & $\begin{array}{l}\text { Surge peak } \\
\text { return } \\
\text { period }\left(T_{s}\right)\end{array}$ & $\begin{array}{c}\text { Percentage of } \\
\text { area inundated } \\
\qquad\left(A_{f}\right)\end{array}$ & $\begin{array}{c}\text { Flood type } \\
\text { (P-Pluvial, F- } \\
\text { Fluvio-tidal, S- } \\
\text { Surge, N-No flood) }\end{array}$ \\
\hline 1988 & 9.5 & 3.9 & 6.5 & 10.3 & $\bar{P}$ \\
\hline 1989 & 1.4 & 1.5 & 2.7 & 6.5 & $\mathrm{~N}$ \\
\hline 1990 & 2.1 & 2.1 & 2.4 & 9.3 & $\mathrm{~N}$ \\
\hline 1991 & 1.7 & 1.6 & 1.9 & 8.2 & $\mathrm{~N}$ \\
\hline 1992 & 1.3 & 3.4 & 2.5 & 7.8 & $\mathrm{~N}$ \\
\hline 1993 & 8.1 & 1.8 & 1.5 & 11.4 & $\mathrm{P}$ \\
\hline 1994 & 1.3 & 1.2 & 1.2 & 5.9 & $\mathrm{~N}$ \\
\hline 1995 & 2.8 & 6.4 & 13.4 & 16.5 & $\mathrm{~F}, \mathrm{~S}$ \\
\hline 1996 & 1.4 & 34.6 & 4.3 & 9.2 & $\mathrm{~F}$ \\
\hline 1997 & 2.2 & 1.9 & 2.1 & 9.3 & $\mathrm{~N}$ \\
\hline 1998 & 3.0 & 11.8 & 2.0 & 22.8 & $\mathrm{~F}$ \\
\hline 1999 & 7.9 & 3.6 & 1.8 & 10.8 & $\mathrm{P}$ \\
\hline 2000 & 2.9 & 8.2 & 5.0 & 10.9 & $\mathrm{~F}$ \\
\hline 2001 & 1.7 & 22.7 & 9.2 & 48.1 & $\mathrm{~F}, \mathrm{~S}$ \\
\hline 2002 & 18.8 & 12.3 & 1.5 & 10.7 & $\mathrm{P}, \mathrm{F}$ \\
\hline 2003 & 1.1 & 5.8 & 2.2 & 7.9 & $\mathrm{~N}$ \\
\hline 2004 & 5.2 & 1.3 & 1.0 & 13.1 & $\mathrm{P}$ \\
\hline 2005 & 1.2 & 1.2 & 1.1 & 11.5 & $\mathrm{~N}$ \\
\hline 2006 & 5.7 & 1.6 & 1.2 & 13.0 & $\mathrm{P}$ \\
\hline 2007 & 3.0 & 2.4 & 34.9 & 35.0 & $\mathrm{~S}$ \\
\hline 2008 & 1.4 & 1.5 & 2.8 & 10.1 & $\mathrm{~N}$ \\
\hline 2009 & 1.6 & 4.4 & 22.8 & 21.2 & S \\
\hline 2010 & 1.1 & 1.0 & 1.2 & 6.1 & $\mathrm{~N}$ \\
\hline 2011 & 11.8 & 1.1 & 1.2 & 10.8 & $\mathrm{P}$ \\
\hline 2012 & 1.1 & 1.1 & 1.1 & 7.0 & $\mathrm{~N}$ \\
\hline
\end{tabular}


Fig. 1. South western embanked region of Bangladesh

Fig. 2. Analytical process of this study

Fig. 3. Modelled versus observed pluvial flood inundation plot

Fig. 4. Return level plots with fitted GEV df and 95\% confidence bands

Fig. 5. Classified flood events in relation to values corresponding hydrological parameters

Fig. 6. Simulated pluvial flood inundation for three scenarios

Fig. 7. Impact of polders on pluvial flooding (2004 event)

Fig. 8. Polder wise inundation in two scenarios during (a) fluvio-tidal flood of 1998, and (b) storm surge flood of 2007 


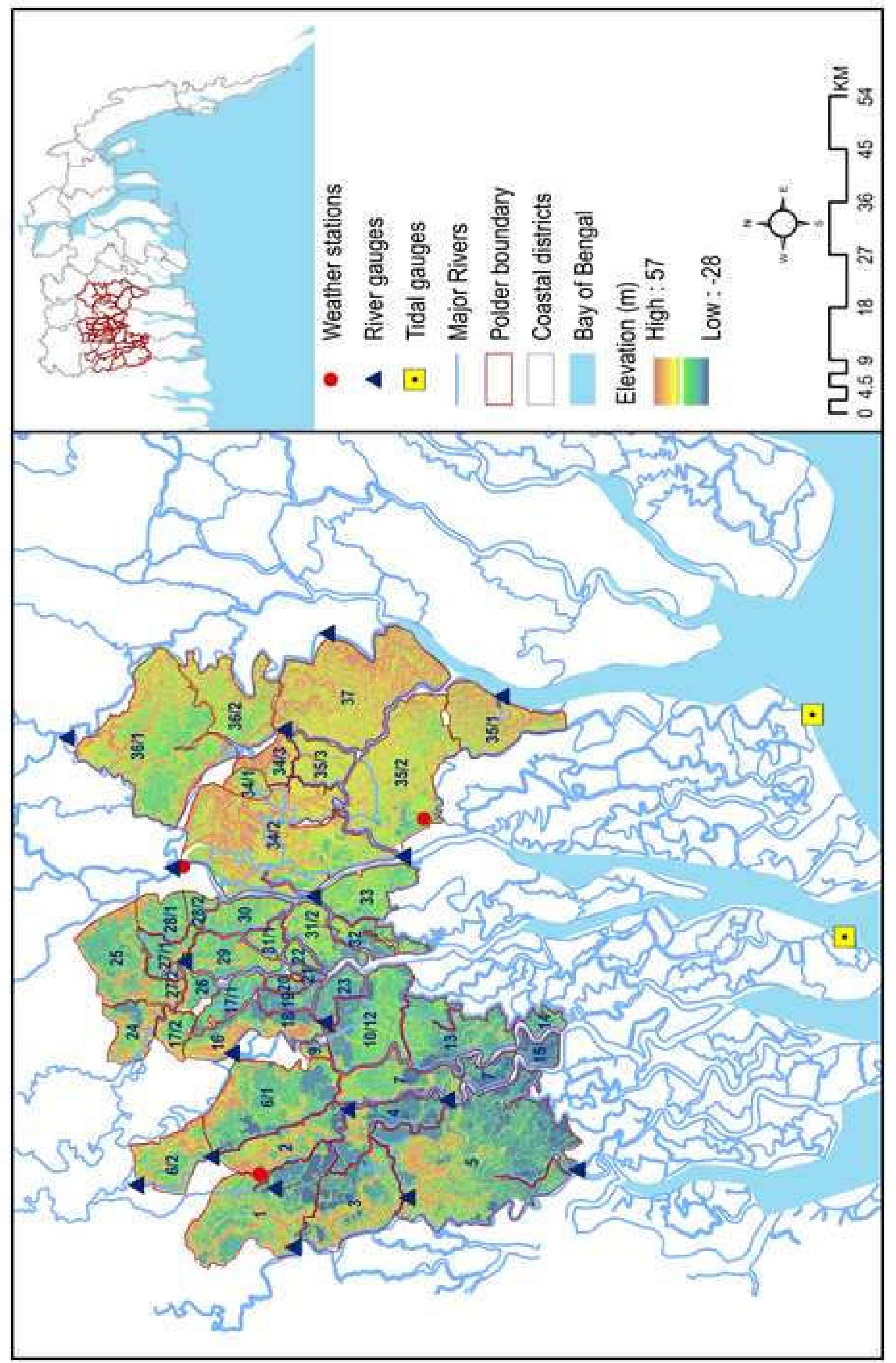




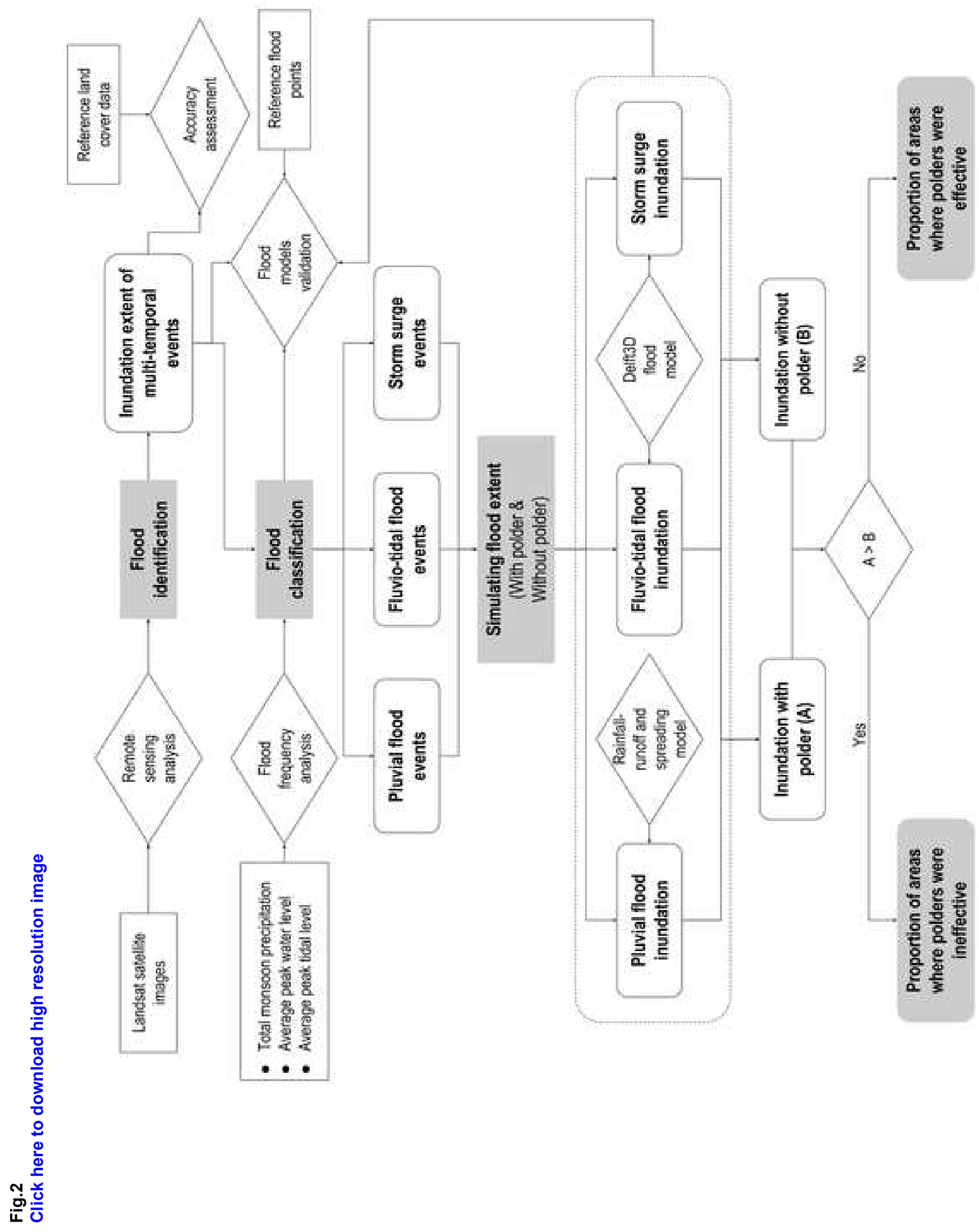




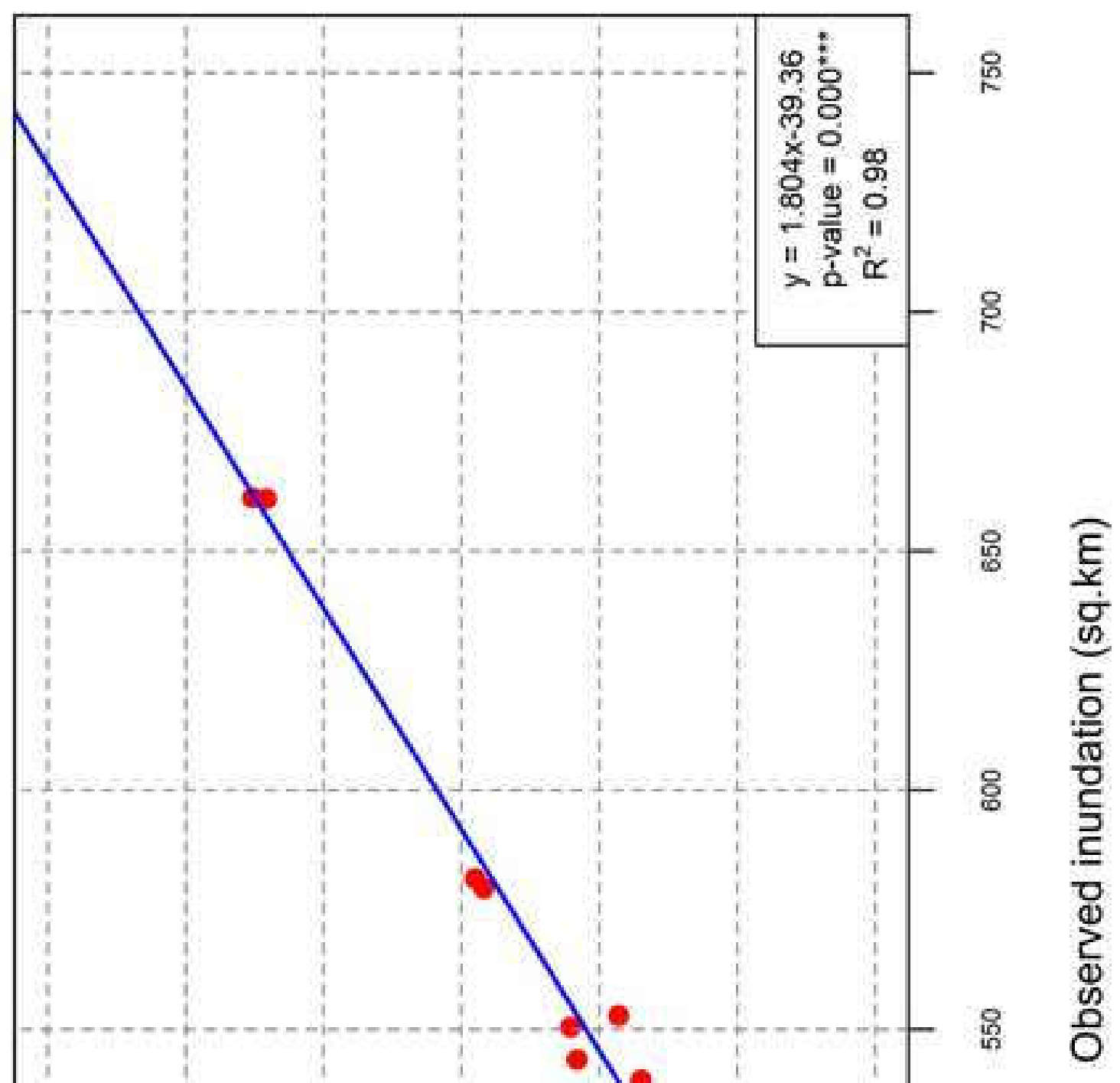

옹

용

(uy bs) uo!̣epunu! pә|әроw 


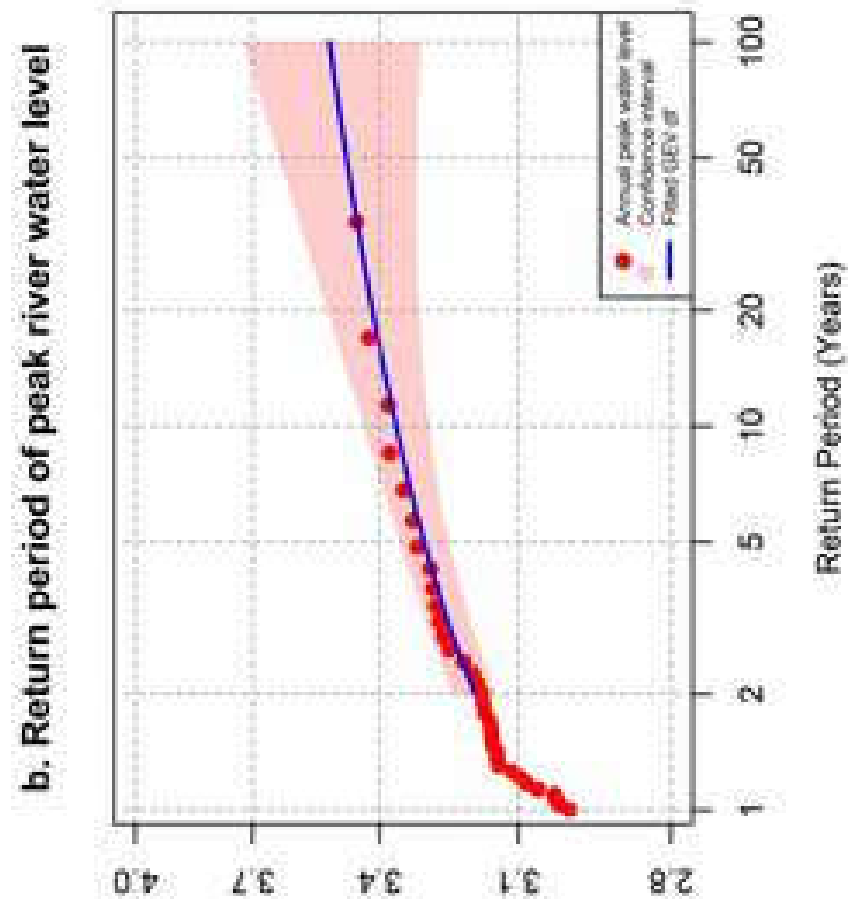

(w) јаме| дәуем xead jenuuy

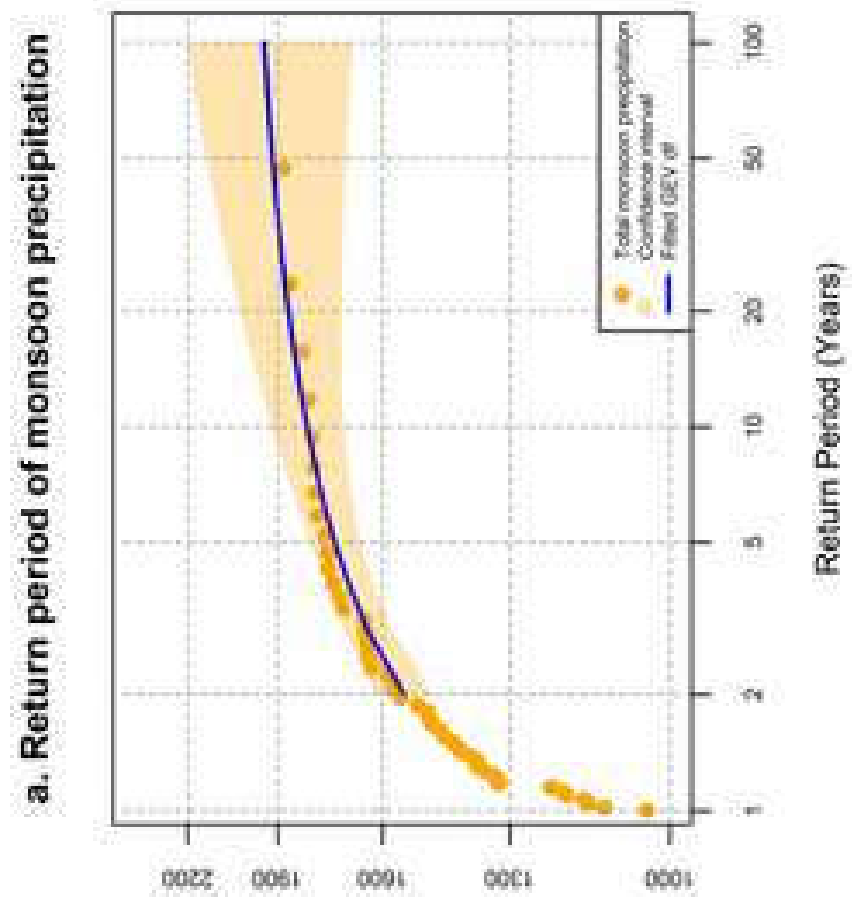

(ww) volgendipasd noosuou jelol

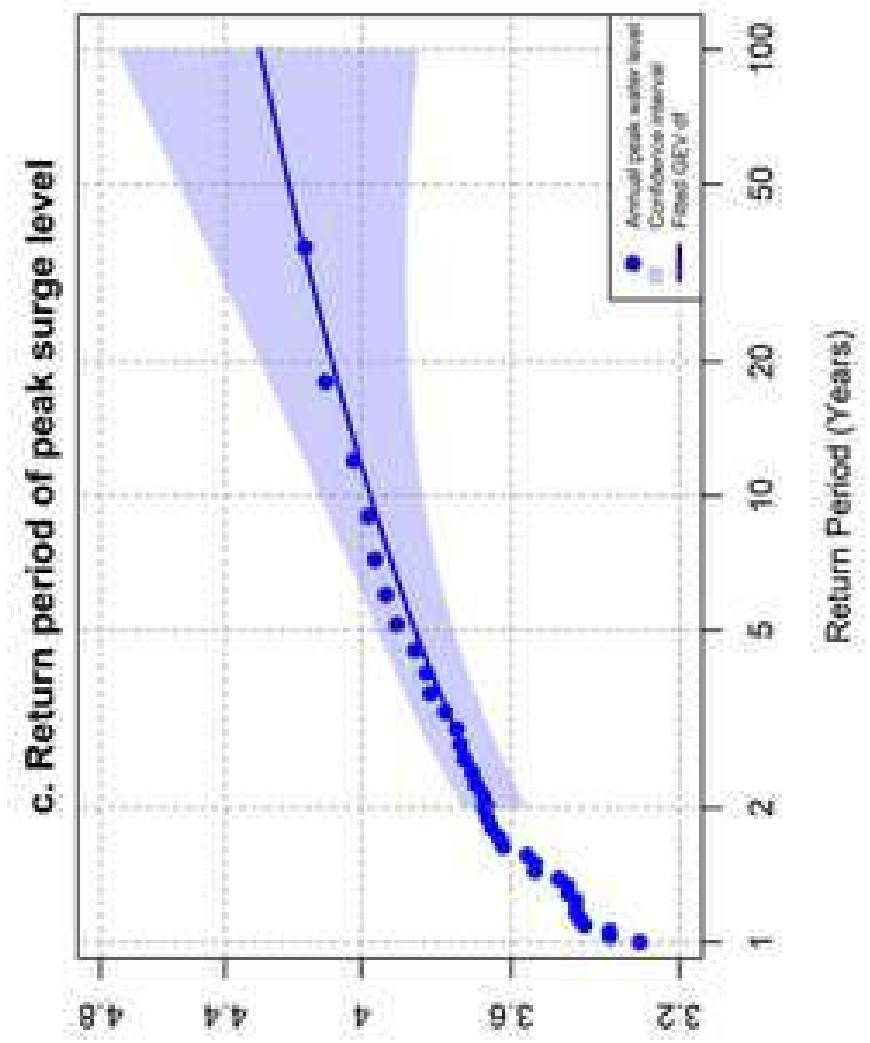

(u) |әмә| sәуем yead jenuü 

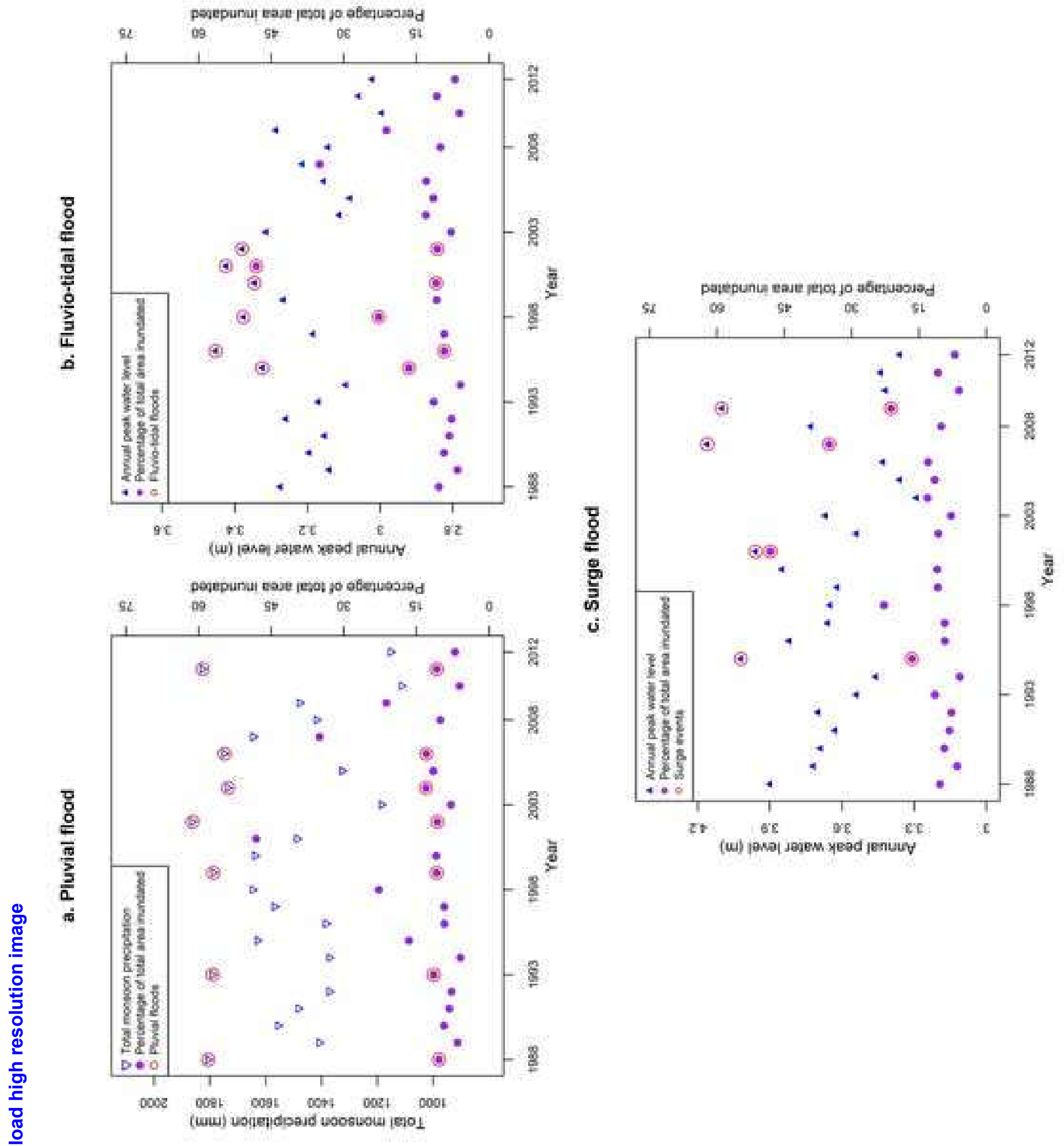


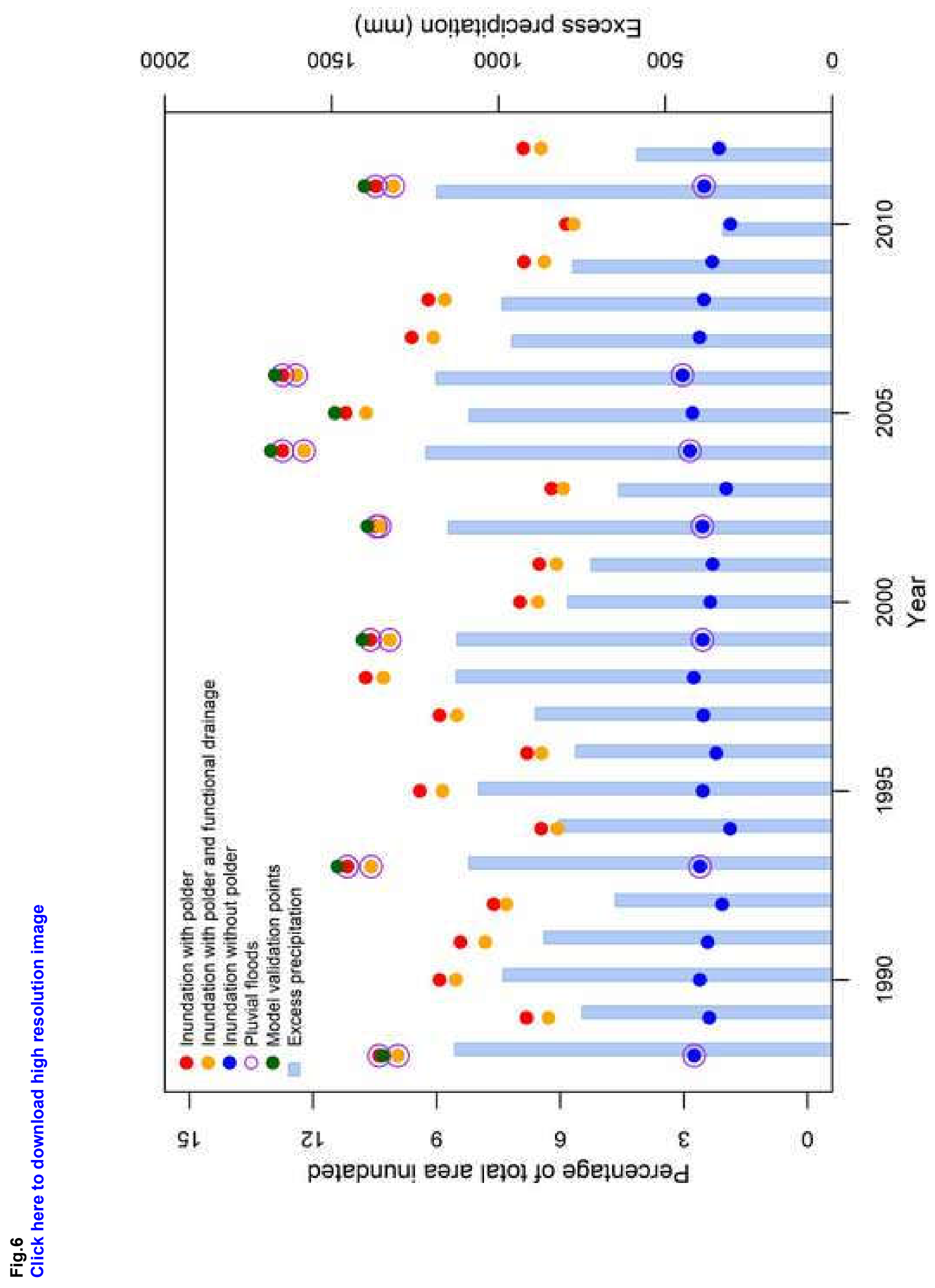




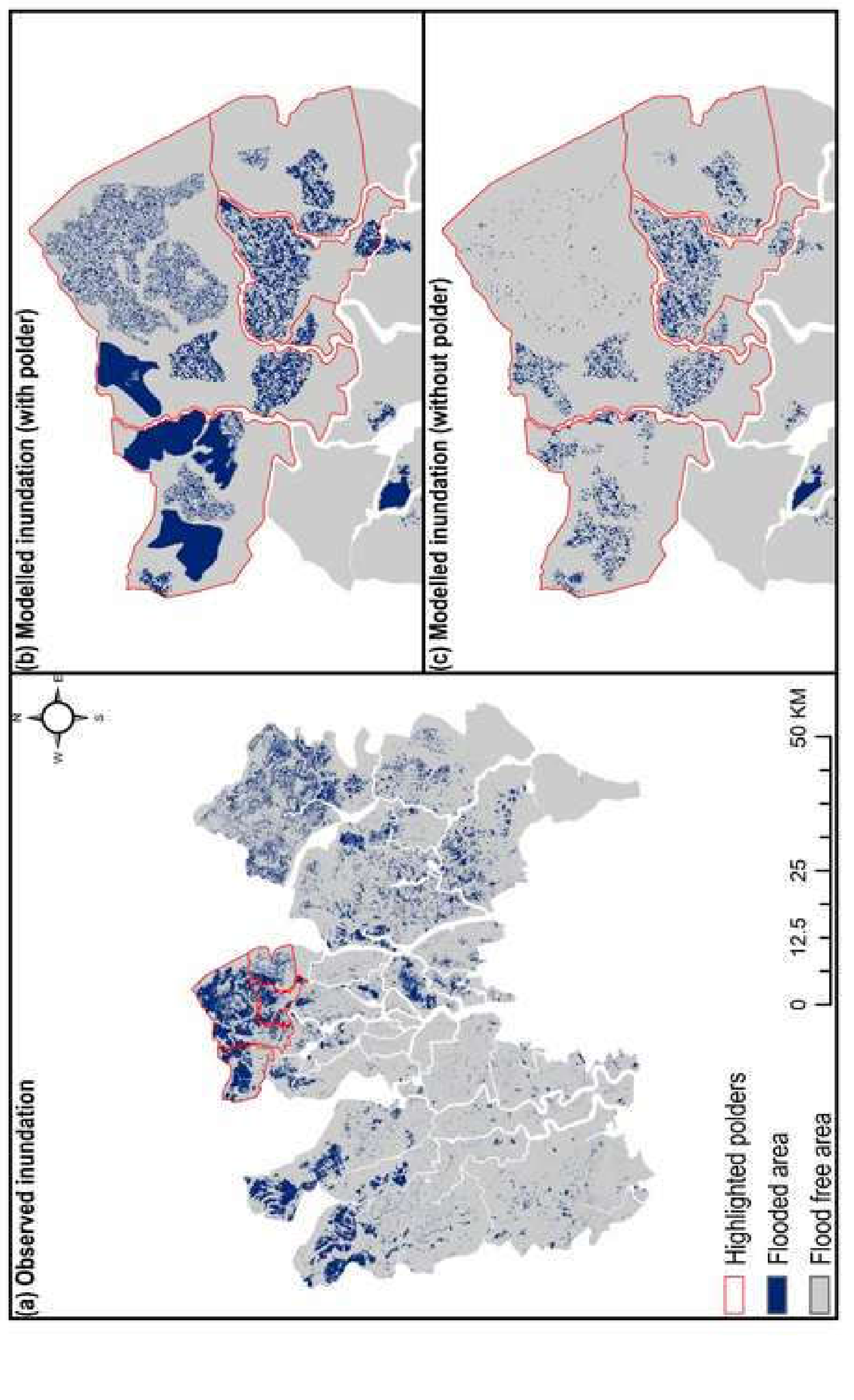



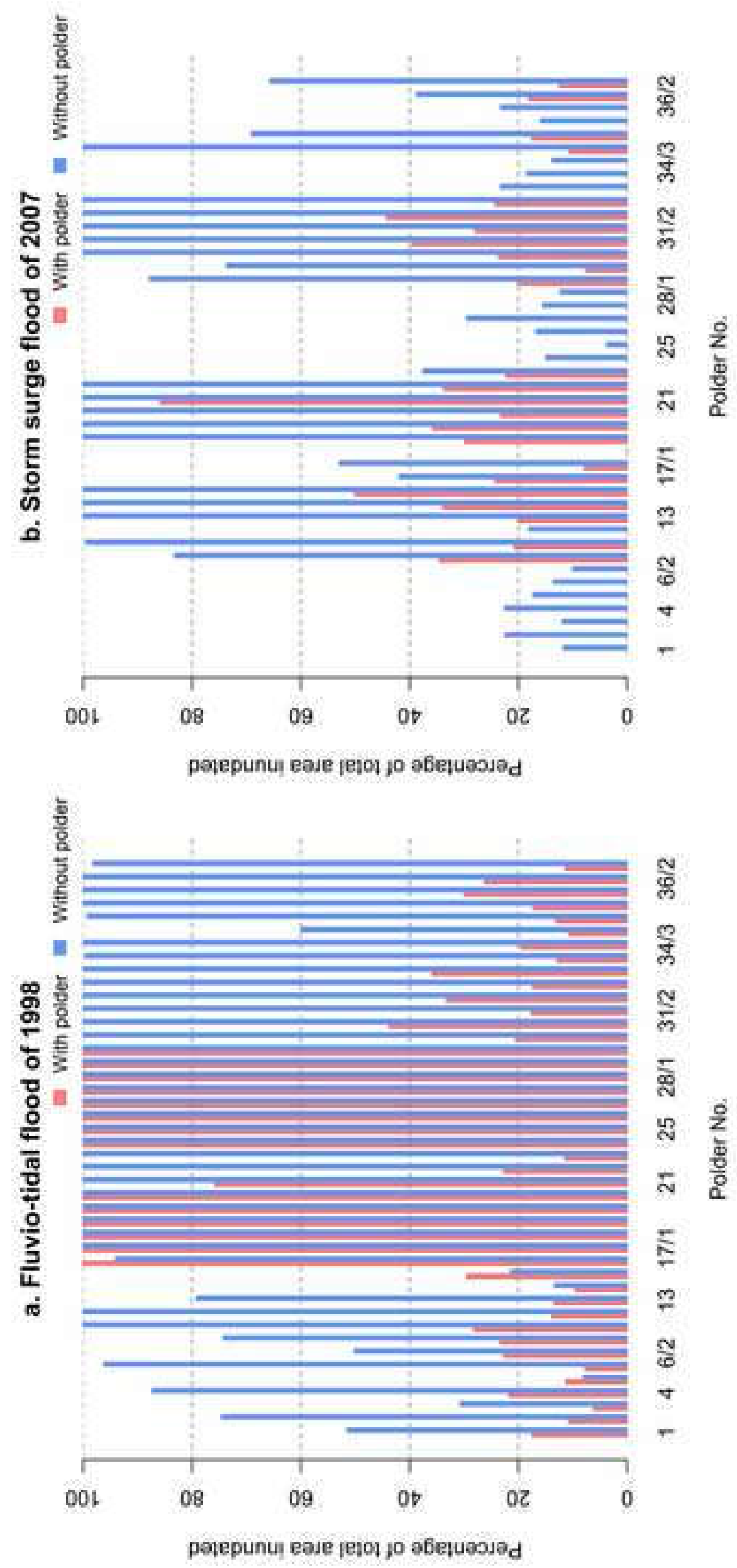

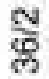

ले

ल

ฐึ

N $\frac{2}{2}$
त $\frac{0}{\circ}$

Е

\%

จ

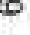

4 
